\title{
The Liveable Cities Method: establishing the case for transformative change for a UK metro
}

Joanne M. Leach BSC, MSC

Research Fellow, Department of Civil Engineering, University of

Birmingham, Birmingham, UK (corresponding author: j.leach@bham.ac.uk)

(Orcid:0000-0001-7526-624X)

Chris D. F. Rogers Eur Ing, BSC, PhD, CEng, MICE, MIHT

Professor of Geotechnical Engineering, Department of Civil Engineering,

University of Birmingham, Birmingham, UK (Orcid:0000-0002-1693-1999)
Adriana Ortegon-Sanchez MSc

Research Associate, Department of Civil, Environmental and Geomatic Engineering, University College London, London, UK

Nick Tyler CBE, PhD, ARCM, CEng, FICE, FRSA, FREng

Director of the UCL Centre for Transport Studies and Chadwick Professor of Civil Engineering, Department of Civil, Environmental and Geomatic

Engineering, University College London, London, UK

There is currently great interest in the creation of sustainable and liveable cities, both in the UK and globally. While it can be argued that good progress is being made in thinking about the needs of future cities, meeting these needs and aspirations in practice poses major challenges of understanding and measurement (what is meant by these terms and how can progress towards their achievement be measured?), complexity (cities are complex systems of systems with many interacting parts) and resilience (will interventions made today be relevant and effective in the future?). The Liveable Cities research programme created a systematic decision-making method for improving urban sustainability and liveability: the Liveable Cities Method (LCM). The LCM prioritises four criteria - individual and societal well-being, resource security, resource efficiency and carbon dioxide emissions as a proxy for environmental harm - in an interconnected framework and assesses the need for, and the resilience of, interventions designed to move cities towards improved sustainability and liveability. This paper illustrates the LCM through an example intervention made to the city of Birmingham, UK, and highlights how addressing sustainability and liveability in this way offers unique opportunities for the UK civil engineering profession to lead thinking among urban professionals.

\section{Introduction: challenges to achieving urban sustainability and liveability}

Civil engineers use ingenuity to address the problems and take advantage of the opportunities posed by society and the dual influences that the environment and economy have on it. They use creative thinking to develop processes and strategies and systems and artefacts, which in many cases are required to function for decades and sometimes even centuries (Balmforth (2015), and, for an example, see the paper by de Silva and Paris (2015)). This means that engineers are well placed to affect progress towards sustainability, resilience and liveability (Pearce et al., 2012) and are encouraged to do so - not least through this journal: see the paper by Fenner et al. (2006) for an early perspective and the papers by Fenner et al. (2014) and Byrne and Mullally (2014) for implications for civil engineering education. Sustainability has been much defined, being enriched from Brundtland's (WCED, 1987) oft-quoted concept of intergenerational equity and opportunity by a multitude of insights published in this journal. Likewise, resilience - ensuring that engineering interventions continue to function and deliver their benefits, in the face of contextual change no matter how rapid (Arup, 2015; LRF, 2015; Rogers et al., 2012a) - is well understood and embraces adaptability as one effective response. However, the longevity of engineered systems and artefacts also means that there is a danger that engineers create path dependencies for problems that are by their nature dynamic and, therefore, deliver outcomes that cease to be efficient and/or effective in the medium to long term. In contrast, liveability is less clearly established (Leach et al., 2017a), a weakness that this paper seeks to address hereafter.
Moreover, the outcomes of the civil engineering profession are inevitably context dependent (Pearce et al., 2012; Shareef and Altan, 2017), and it is this dynamic, changing context that adds to the complexity of the civil engineer's role in serving society (see the paper by Roohnavaz (2017) for the implications for construction projects in developing countries).

Given that the changing contexts in which civil engineers currently operate include a markedly growing population, increasing urbanisation, climate change and a changing demography (Balmforth, 2015; Hunt et al., 2018; UN Desa Population Division, 2014), improving the performance of cities provides one of the primary points of focus for the civil engineer. In turn, it is a vision of cities of the far future that must inform today's activities if future outcomes are to deliver the efficiency and efficacy that the often considerable investment demands within the context of sustainability and liveability (Rogers, 2018). This leads to fundamental questions of what is the nature of cities of the future and, more specifically, what is the nature of citizens and societies of the future? Also, what is 'the nature of any compromises or trade-offs that need to be made in balancing such requirements in order for us [engineers] to be explicit about the impacts associated with our choices'? (Gaterell, 2016: p. 223) the focus of a recent issue of this journal. Answers are required to develop policies and strategies, and associated briefs and designs, for future sustainable and liveable city systems and the infrastructures and organisations that support them (see the paper by Whitehead (2015) for a case study of Balfour Beatty's sustainability journey). 
While there is great interest in the creation of sustainable and liveable cities, both in the UK and globally, there is no convergence as to the best processes for achieving the desired outcomes (Leach et al., 2016a). The need for tools and techniques to enable engineers to engage in the many and varied decisionmaking processes involved in improving sustainability was recognised by this journal in 2013 (Gaterell, 2013). At about the same time, the research programme Liveable Cities (LC) (LC, 2018) set out to transform the engineering of cities by ensuring that radical engineering solutions to the problem of engineering future sustainable and liveable cities take into account the human dimensions of living and working in a city, including quality of life, well-being and citizen aspirations. One outcome is a systematic decision-making method for improving urban sustainability and liveability: the Liveable Cities Method (LCM).

This paper introduces the nine-step LCM, a decision-making process that identifies potential barriers to achieving urban sustainability and liveability by making explicit how strategic ambitions (i.e. for the desired future performance of a city and its citizens) link to operational activities (i.e. interventions) and how vulnerable operational activities are to future change. The LCM enables users to explore possibilities and aspirations for a city as opposed to being a deterministic procedure towards quantifiable results. Importantly, it is applicable across scales, which is crucial within a multiscalar discipline such as engineering (Gaterell (2016), see also the editorial by Keaton (2017) for a brief discussion about the scales at which the concepts of sustainability and resilience operate and their relevance for geotechnical engineering). This paper illustrates the LCM through the example of an intervention made to the city of Birmingham. It highlights how addressing sustainability and liveability in this way offers unique opportunities for the UK civil engineering profession to lead thinking among urban professionals.

This section has briefly described some of the challenges for engineers in achieving sustainability and liveability in cities. The following section describes and illustrates through a case study how the LCM can be used to address them. This is followed by reflection on the implications for UK civil engineering. Crucially, the LCM, and its extensive evidence base (LC, 2018), has the potential to transform the engineering of cities to deliver a more profound set of benefits when meeting the basic needs of cities and their infrastructure systems.

\section{The LCM: a method for improving urban sustainability and liveability and its application to the city of Birmingham, UK}

The LCM was developed from a comprehensive review of the sustainability, resilience, liveability and city performance, measurement and assessment literature; primary research to address the evident research gap; a series of consultations with local authorities, urban designers and planners and other urban experts from the private, public and third sectors (including academics); and testing in three UK cities: Birmingham, Lancaster and Southampton (Leach et al., 2017a). It builds on the Designing Resilient Cities Method (Lombardi et al., 2012; Rogers et al., 2012b), which is incorporated into the LCM and is shown in Figure 1 as steps 5 to 9 .

The LCM assesses the need for and the vulnerability of interventions designed to move cities towards improved sustainability and liveability. Figure 1 illustrates the LCM's nine steps, acknowledging that the illustration presents only the very essence of the process (its critical path) and strips away the inevitable messiness and iterative nature of decision-making (Mintzberg and Westley, 2001). However, iteration is an essential part of engineering decision-making processes - it is the mature engineering response to systems thinking - and will occur throughout steps 1-5 and, once step 9 has been reached, a return to any of steps $1-5$ might happen to refine the thinking. Only once the intervention has been finalised can its likely resilience be determined using the Designing Resilient Cities Method by following steps 5-9.

\subsection{Step 1: identify desired future performance and its intended multiple benefits (performance-benefit pairs)}

The first step in the LCM is for a city to identify what it wants to be like in the future (i.e. its desired future performance). For each element of performance, concomitant 'intended benefits' (i.e. the benefits that have been designed to arise from implementing performance improvement measures, which will take the form of 'interventions' in the city and its infrastructure systems) should be identified, where possible taking advantage of multiple intended benefits (Rogers, 2018). If more than one intended benefit is identified, then the LCM should be followed for each intended benefit.

Describing future performance (desired or predicted) is a subject of great interest, and there exist several approaches (GOScience, 2016a; Hunt and Rogers, 2015a; Rogers, 2018). However, none of the approaches is specific to LC's four criteria (individual and societal well-being, resource security, resource efficiency and carbon dioxide emissions). In order to identify performance-benefit pairs relevant to these criteria effectively, LC created a vision for a future sustainable and liveable city - the Ideal City Model (Ortegon-Sanchez and Tyler, 2015) (see Figure 2) - and this model will be used herein to illustrate the LCM. The Ideal City Model incorporates five future city visions (desired performances) and their underlying principles (which will inform the intended benefits of city interventions); see Table 1.

From the Ideal City Model, one desirable future performance is to create an 'active and inclusive city'. This is chosen as the case study for this paper because it complements the city of Birmingham's objectives ' $[t]$ o develop Birmingham as a city of sustainable neighbourhoods that are safe, diverse and inclusive with locally distinctive character' and ' $[\mathrm{t}] \mathrm{o}$ provide high quality connections throughout the City and with other places including 


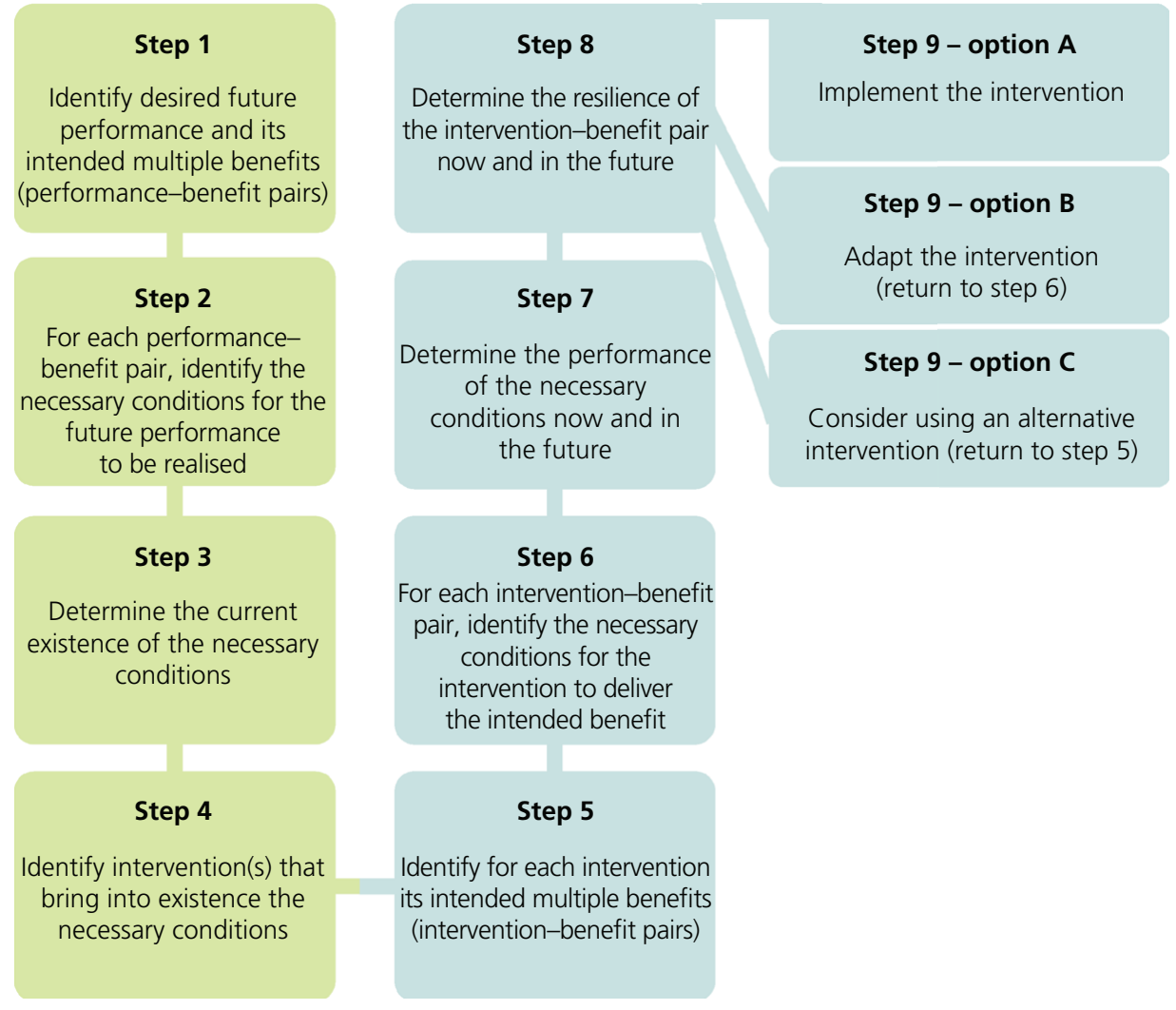

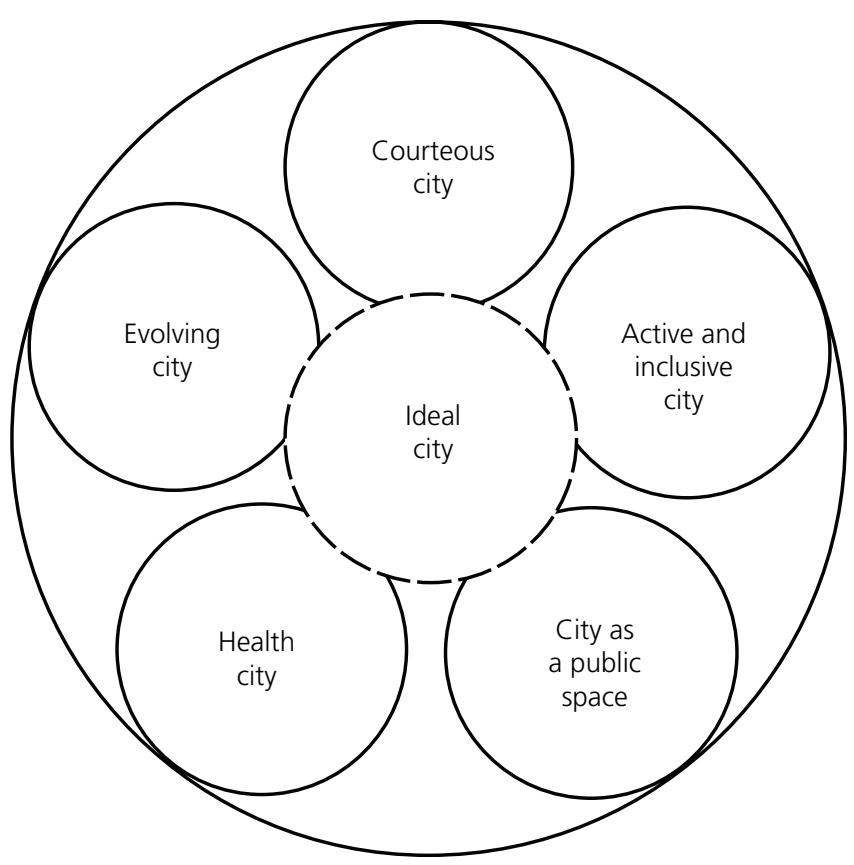

Figure 2. The LC's Ideal City Model. Adapted from OrtegonSanchez and Tyler (2015) encouraging the increased use of public transport, walking and cycling' (Birmingham City Council, 2017: p. 18). Moreover, and importantly, it aligns well with the aspirations of Birmingham's stakeholders (Hunt and Rogers, 2015b).

Creating an active and inclusive city has an intended benefit of 'ensuring people's fair access to opportunities to meet their needs and aspirations'. Achieving this intended benefit means, among other things, enabling affordable, safe, sustainable and accessible mobility, including active mobility, and that there need to be public transport options that promote walking and cycling as part of the overall journey (see the paper by Deegan (2016) for a useful analysis of the London Cycle Network Plus project). There are, of course, other aspects to creating an active and inclusive city, such as ensuring opportunities (employment) and other activities (leisure, culture, education, health) which are not only accessible physically and spatially, but also accessible financially (affordable) to promote inclusiveness. There are also additional benefits to be generated by creating not just an active and inclusive city, but also a healthy city and an evolving city and so on. This paper will focus on 'enabling affordable, safe, sustainable and accessible mobility, including active mobility' and the additionalities described earlier will not be pursued, but it is to be noted that it is in the bringing together of multiple desirable 
Table 1. The LC's Ideal City Model: future performance and intended benefits

\begin{tabular}{|c|c|}
\hline Future performance & Intended benefits \\
\hline Courteous city & Stimulates positive social interactions and promotes behaviours that facilitate the functionality of the city \\
\hline Active and inclusive city & Ensures people's fair access to opportunities to meet their needs and aspirations \\
\hline City as a public space & $\begin{array}{l}\text { All public spaces are designed as open and accessible to provide protection, safety and security and create a sense } \\
\text { of belonging and ownership }\end{array}$ \\
\hline Healthy city & Ensures the good health of people and the environment today and for future generations \\
\hline Evolving city & $\begin{array}{l}\text { Designed to be adaptable, flexible, innovative and responsive, particularly for its soft infrastructures (i.e. } \\
\text { governance, policies, financing and economy, among others), and which learns and adapts dynamically } \\
\text { accordingly to people's behaviours }\end{array}$ \\
\hline
\end{tabular}

Adapted from Ortegon-Sanchez and Tyler (2015)

future performances and their benefits where the strength of the LCM lies

- performance: to create an active and inclusive city

- benefit: to ensure people's fair access to opportunities to meet their needs and aspirations by enabling affordable, safe, sustainable and accessible mobility, including active mobility.

\subsection{Step 2: identify the necessary conditions for the future performance to be realised}

The next step in the LCM is to identify the conditions that are necessary to enable delivery of the intended benefit. It is helpful here to consider 'what if?' questions for changes in society, technology, economy, environment and policy (a Steep analysis) (Lombardi et al., 2012). Quantitative modelling can also be employed (Hall et al., 2017). It is also helpful to consider the current barriers to achieving the desired future performance. One way of doing this is to backcast from the desired future performance to today's performance, which was undertaken for this study. UK City Liveability Indicators Framework Edition 1 (UK City Life ${ }_{1}$ ) (Leach et al., 2017a) was used to describe the current performance of Birmingham, UK, although numerous other city measurement and assessment frameworks exist and can be used (Astleithner and Hamedinger, 2003; Colantonio, 2010; Kitchin et al., 2015; Leach et al., 2015; Mayer, 2008; Ness et al., 2007; Pires et al., 2014). For the authors' identified performance-benefit pair, the following necessary conditions were identified (noting that this list is kept purposefully simple).

The necessary conditions required to enable affordable, safe, sustainable and accessible mobility, including active mobility for the purpose of creating an active and inclusive city, are

n that affordable, safe, sustainable and accessible transport alternatives exist where they are needed

- that affordable, safe, sustainable and accessible transport options will exist into the future

- that affordable, safe, sustainable and accessible transport options are environmentally, socially and economically sustainable

- that low-carbon dioxide ('low-carbon') options exist where affordable, safe, sustainable and accessible transport is not feasible (e.g. during inclement weather, under time and distance constraints)

- that the urban form facilitates affordable, safe, sustainable and accessible mobilities (i.e. an equitable land use mix within the city)

- that transport options (in particular public transport) provide the required linkages (e.g. suburbs to centre) and are affordable, safe, sustainable and accessible for all.

\subsection{Step 3: determine the current existence of the necessary conditions}

Step 3 asks if each necessary condition currently exists. This requires judgement and synthesis, drawing on expertise, experience and knowledge of the local context. This also requires knowledge of the city's current performance, and UK City Life ${ }_{1}$ has been used here to assess the current performance of Birmingham, UK (Leach et al., 2017b) alongside an in-depth review of Birmingham's transport ecosystem (Leach et al., 2016b). The results of this analysis can be found in Table 2, noting that they have been vastly simplified in order to retain clarity (UK City Life 1 contains a total of 346 potentially relevant indicators of city performance, from which the most relevant have been chosen to illustrate the method).

\subsection{Step 4: identify interventions that bring into existence the necessary conditions}

Once the existence or absence of the necessary conditions is known, it becomes possible to design interventions (i.e. potential solutions to problems) that can overcome the barriers to and exploit the opportunities for bringing the necessary conditions into being and thus achieve the desired future performance. Interventions can be anything from physical interventions (and for engineers this often means infrastructure, which is highly interdependent with and interconnected with policies promoting behaviour change (Montgomery et al., 2012)). In some cases, large-scale interventions are demanded; in others, a portfolio of smaller interventions is preferable. How these play out for desirable long-term agendas may vary: '[s]ustainable options can be mundane, as well as magnificent' (Keaton, 2017: p. 1).

For the purpose of this example, an intervention that was in the process of being implemented in 2016 has been chosen. This 
Table 2. Existence of the necessary conditions in Birmingham, UK

\begin{tabular}{|c|c|}
\hline Necessary condition & Existence in Birmingham (base year 2016) \\
\hline $\begin{array}{l}\text { That affordable, safe, sustainable and accessible transport } \\
\text { alternatives exist where they are needed }\end{array}$ & $\begin{array}{l}\text { At risk, as buses and taxis were (and still are) the primary public transport } \\
\text { alternatives in Birmingham, and these are privately operated. Walking and } \\
\text { cycling in the city centre requires improvement in terms of wayfinding, quality } \\
\text { of the environment and connectivity of public transport systems }\end{array}$ \\
\hline $\begin{array}{l}\text { That affordable, safe, sustainable and accessible transport } \\
\text { options will exist into the future }\end{array}$ & $\begin{array}{l}\text { At risk, as bus and taxi operators need to make a profit and so operate } \\
\text { accordingly. The cycling network in Birmingham is being expanded, but in the } \\
\text { least-cost, least disruptive way (e.g. through existing canal towpaths), and while } \\
\text { some will be 'protected', those associated with road layouts could easily be } \\
\text { reversed }\end{array}$ \\
\hline $\begin{array}{l}\text { That affordable, safe, sustainable and accessible transport } \\
\text { options are environmentally, socially and economically } \\
\text { sustainable }\end{array}$ & $\begin{array}{l}\text { At risk, as they were (and still are) primarily buses and taxis - which currently } \\
\text { respond primarily to commercial (i.e. economic) pressures - and more limited } \\
\text { walking and cycling - and these modes of transport require improvement and } \\
\text { protection in Birmingham (see other necessary conditions for commentary on } \\
\text { some of these) }\end{array}$ \\
\hline $\begin{array}{l}\text { That low-carbon options exist where affordable, safe, } \\
\text { sustainable and accessible transport is not feasible (e.g. } \\
\text { during inclement weather, under time and distance } \\
\text { constraints) }\end{array}$ & $\begin{array}{l}\text { No, as in Birmingham taxis and buses were the main public transport alternatives } \\
\text { (although there are now air quality targets for these modes of transport) }\end{array}$ \\
\hline $\begin{array}{l}\text { That the urban form facilitates affordable, safe, sustainable } \\
\text { and accessible mobilities (i.e. an equitable land use mix } \\
\text { within the city) }\end{array}$ & $\begin{array}{l}\text { No, as there were (and still are) local concentrations of employment, retail and } \\
\text { housing of different types throughout the city }\end{array}$ \\
\hline $\begin{array}{l}\text { That transport options (in particular, public transport) } \\
\text { provide the required linkages (e.g. suburbs to centre) and } \\
\text { are affordable, safe, sustainable and accessible for all }\end{array}$ & $\begin{array}{l}\text { No, as buses and trains were (and still are) ineffective in connecting the suburbs } \\
\text { to the city centre in many cases: for many, these are not a reliable mode of } \\
\text { travel, and few alternatives exist for 'hop-on, hop-off' travel }\end{array}$ \\
\hline
\end{tabular}

intervention addresses the existence of the necessary condition 'that low-carbon options exist where affordable, safe, sustainable and accessible transport is not feasible (e.g. during inclement weather, under time and distance constraints)'. In Birmingham, the electric light rail (Metro) was undergoing a phased expansion that in 2016 saw it extended into the city centre as a low-carbon alternative to traversing the wider city centre area and, in particular, connecting to the Birmingham New Street railway station, a major station on the UK passenger rail system (Bourke, 2015) - see Figure 3

- intervention: extending Birmingham's light rail (Metro) into the city centre

n to satisfy the necessary condition: that low-carbon options exist where affordable, safe, sustainable and accessible transport is not feasible (e.g. during inclement weather, under time and distance constraints).

It is beyond the scope of this paper to explore the possible additionalities afforded by interventions that address more than one necessary condition, but it should be noted that doing so is important when engaging in a full analysis. For example, the Metro extension could have been designed to satisfy the following necessary condition additionally: 'that transport options (in particular public transport) provide the required linkages (e.g. suburbs to centre) and are affordable, safe, sustainable and accessible to all'. If this were the case, then the Metro would be designed not only to provide a service in the city centre and its immediate surroundings, but also to connect in a systematic manner the city's suburbs to its city centre (not currently part of the phased extension plans, although the authors acknowledge

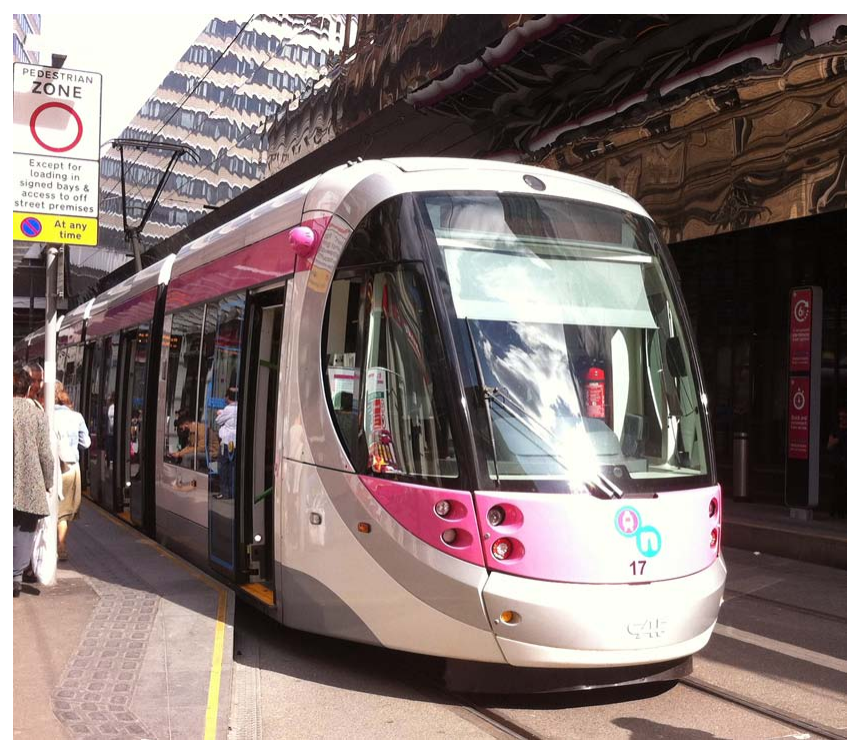

Figure 3. The Birmingham City Centre Metro extension outside the New Street railway station

that such plans may be part of a long-term strategy not in the public domain). In other words, the Metro extension plan does not appear to deliver a strategic suite of necessary conditions.

\subsection{Step 5: identify for each intervention its intended multiple benefits (intervention-benefit pairs)}

Once designed, an intervention must be tested for potential future vulnerabilities, as well as its potential in maximising the range of 
additional benefits that it might realise, and redesigned and retested as necessary. Although there exist a number of tools and methodologies for achieving this - and particularly so within engineering (Pearce et al., 2012) - the Designing Resilient Cities Method is relevant as it uses UK-based future urban scenarios to pressure-test the resilience of interventions to future change. A full description of this method alongside examples and case studies is available from the book by Lombardi et al. (2012) and the paper by Rogers et al. (2012b). As such, the Designing Resilient Cities Method has been revised and incorporated into the LCM and comprises steps 5-9.

Step 5 requires that, for each intervention, intended benefits are identified (intervention-benefit pairs). Where more than one intended benefit is identified (multiple benefits), then steps 5-9 should be carried out for each intended benefit (Lombardi et al., 2012). It is also possible to use UK City Life ${ }_{1}$ to identify multiple benefits. A description of how this works for the Metro extension is available in the paper by Leach et al. (2016a). Identifying multiple benefits is desirable, but beyond the scope of this paper. The intervention-benefit pair identified from this paper's example is

- intervention: Birmingham's light rail (Metro) city centre extension

- intended benefit: to create a low-carbon, public transport option in the city centre that is affordable, safe, sustainable and accessible.

\subsection{Step 6: for each intervention-benefit pair, identify the necessary conditions for the intervention to deliver the intended benefit}

Next, taking each intervention-benefit pair in turn, the conditions that enable the intervention to keep functioning and delivering its intended benefit into the future are identified. In other words, what are the conditions that enable people to use the intervention so that it delivers its intended benefit (Lombardi et al., 2012)? Necessary conditions can be identified by using the previously identified methods as well as by using quantitative modelling and assessment. For this example, the authors have identified the following necessary conditions (the list has been kept purposefully short and simple in order to retain clarity)

a that the Metro connects the city centre in useful ways

v that the Metro is reliable

v that the Metro is affordable to all

a that the Metro is safe to use

- that the Metro is sustainable (economically, socially and environmentally)

- that the Metro is accessible to all.

\subsection{Step 7: determine the performance of the} necessary conditions now and in the future

Step 7 guides the user in determining whether each necessary condition is present now and if it is likely to be present in the future. Regarding the 'now', the user should make their determination in the most appropriate way, such as by reviewing documentation, observation and deduction. Regarding the 'future', there exist a number of ways of determining the presence of necessary conditions (Rogers, 2018). For consistency, the authors have used the Designing Resilient Cities Method for this purpose. Table 3 shows the outcome of this analysis. The Designing Resilient Cities Method uses future scenarios to pressure-test the existence of each necessary condition in each of four extreme, yet plausible, futures in different directions of travel from today's world. The reasoning is that, if a necessary condition exists today and in the four scenarios, then it is likely to exist no matter how the future actually develops since the scenarios cover the essential range of societal structures (Lombardi et al., 2012). The four scenarios are 'Fortress world', 'Market forces', 'Policy reform' and 'New sustainability paradigm' (see Figure 4). Fortress world is characterised by a bifurcated society: the 'haves' (i.e. the rich and empowered) and the 'have-nots' (i.e. the poor and disenfranchised). Market forces lets the free market dominate unrestricted by social and environmental concerns. Policy reform steers citizens towards sustainability through policy interventions and strong governance, whether citizens and businesses like it or not. New sustainability paradigm is characterised by citizens who want to live as sustainably as possible (Lombardi et al., 2012).

\subsection{Step 8: determine the resilience of the intervention-benefit pair now and in the future}

At this point, it becomes possible to determine the current and future resilience of the intervention. This requires judgement and synthesis, prioritising the importance of the necessary conditions and balancing these against the potential vulnerabilities identified (Lombardi et al., 2012). From the simplified example presented here, it is evident that Birmingham's Metro extension delivers a 'low-carbon, public transport option in the city centre that is affordable, safe, sustainable and accessible' only if the world view embraced by the city develops towards New sustainability paradigm - thus it is at risk - unless strong governance safeguards are put in place to legislate for its continued service functionality (affordability, accessibility etc.). It is also evident that the market cannot deliver the intended benefit on its own; reliance on policy might result in delivery compromises and there is a clear polarisation of service delivery between the rich and the poor.

\subsection{Step 9: (a) implement the intervention, (b) adapt the intervention (and return to step 6) or (c) consider using an alternative intervention (and return to step 5)}

It is now up to the user to decide whether (and how) to implement the intervention; adapt it to make it more resilient to future change or to deliver additional benefits; or replace it altogether. The LCM informs this decision by elucidating the implications of implementing the intervention without adjustments and identifying how the intervention can be improved. For example, for Birmingham's Metro line extension, accessibility and affordability are highlighted as particular vulnerabilities. Birmingham may therefore wish to address explicitly these aspects of the 
Table 3. Future performance of necessary conditions determined using the Designing Resilient Cities Method

\begin{tabular}{|c|c|c|c|c|c|}
\hline $\begin{array}{l}\text { Necessary } \\
\text { conditions }\end{array}$ & Now (2016) & Fortress world & Market forces & Policy reform & $\begin{array}{c}\text { New sustainability } \\
\text { paradigm }\end{array}$ \\
\hline $\begin{array}{l}\text { Connects the city } \\
\text { centre in useful } \\
\text { ways }\end{array}$ & $\begin{array}{l}\text { At risk. The expansion } \\
\text { of the Metro is } \\
\text { currently incomplete } \\
\text { and relies, at least in } \\
\text { part, on the } \\
\text { completion of the } \\
\text { national high-speed } \\
\text { rail link between } \\
\text { London and } \\
\text { Birmingham (High } \\
\text { Speed 2) }\end{array}$ & $\begin{array}{l}\text { Haves: yes, as the } \\
\text { money is available } \\
\text { and other resources } \\
\text { are scarce, so } \\
\text { maximum } \\
\text { functionality must be } \\
\text { achieved } \\
\text { Have-nots: at risk, as } \\
\text { money and other } \\
\text { resources to achieve } \\
\text { connectivity to poorer } \\
\text { areas are scarce }\end{array}$ & $\begin{array}{l}\text { At risk, as the route } \\
\text { and stops will be } \\
\text { determined by } \\
\text { their potential for } \\
\text { making a profit }\end{array}$ & $\begin{array}{l}\text { Yes, as this will have } \\
\text { been required as part } \\
\text { of the permission } \\
\text { granted by the city to } \\
\text { extend the Metro, and } \\
\text { it will be retained as } \\
\text { part of strong } \\
\text { governance of such } \\
\text { city assets }\end{array}$ & $\begin{array}{l}\text { Yes, as this will be } \\
\text { desired by the city, the } \\
\text { citizens and the } \\
\text { Metro's operators (all } \\
\text { of whom will value } \\
\text { the social and } \\
\text { environmental, as well } \\
\text { as economic, benefits } \\
\text { it delivers) }\end{array}$ \\
\hline Is reliable & $\begin{array}{l}\text { Yes, as the Metro } \\
\text { system runs mostly to } \\
\text { schedule. In addition, } \\
\text { in the city centre, the } \\
\text { trams run close } \\
\text { together, enabling a } \\
\text { hop-on, hop-off user } \\
\text { experience }\end{array}$ & $\begin{array}{l}\text { Haves: yes, as there is } \\
\text { money and a safety } \\
\text { imperative for this } \\
\text { Have-nots: at risk, as } \\
\text { services to the } \\
\text { disenfranchised poor } \\
\text { will be a low priority } \\
\text { in financially } \\
\text { constrained times }\end{array}$ & $\begin{array}{l}\text { Yes, as reliability is } \\
\text { linked to greater } \\
\text { usage and thus } \\
\text { greater profits }\end{array}$ & $\begin{array}{l}\text { At risk, as although } \\
\text { reliability can be } \\
\text { legislated, in practice, } \\
\text { those maintaining the } \\
\text { Metro may not be as } \\
\text { rigorous or respond to } \\
\text { breakdowns as quickly } \\
\text { as necessary }\end{array}$ & $\begin{array}{l}\text { Yes, as this will be } \\
\text { desired by the city, the } \\
\text { citizens and the } \\
\text { Metro's operators (all } \\
\text { of whom will value } \\
\text { the social and } \\
\text { environmental } \\
\text { benefits that it } \\
\text { delivers) }\end{array}$ \\
\hline Is affordable to all & $\begin{array}{l}\text { At risk. Although the } \\
\text { Metro is competitively } \\
\text { priced, it is not free } \\
\text { and so inevitably } \\
\text { excludes some } \\
\text { members of society }\end{array}$ & $\begin{array}{l}\text { Haves: yes, as the } \\
\text { 'haves' are (relatively) } \\
\text { wealthy } \\
\text { Have-nots: at risk, as } \\
\text { the 'have-nots' are } \\
\text { poor and their } \\
\text { accessibility needs } \\
\text { will not be prioritised }\end{array}$ & $\begin{array}{l}\text { No, as this would } \\
\text { probably reduce } \\
\text { the profit margin - } \\
\text { market forces will } \\
\text { determine the } \\
\text { most profitable } \\
\text { charging structure }\end{array}$ & $\begin{array}{l}\text { At risk, as, although } \\
\text { prices for travel can be } \\
\text { legislated, there will } \\
\text { be many demands on } \\
\text { budgets and priorities } \\
\text { will determine this } \\
\text { aspect of service } \\
\text { provision }\end{array}$ & $\begin{array}{l}\text { Yes, as this will be } \\
\text { desired by the city, the } \\
\text { citizens and the } \\
\text { Metro's operators (all } \\
\text { of whom will value } \\
\text { the social benefits that } \\
\text { affordability delivers) }\end{array}$ \\
\hline Is safe to use & $\begin{array}{l}\text { At risk. The Metro is } \\
\text { built to a high } \\
\text { standard with safety } \\
\text { as a priority, but } \\
\text { economic factors } \\
\text { (cost) will have } \\
\text { impacted this }\end{array}$ & $\begin{array}{l}\text { Haves: yes, as safety is } \\
\text { a priority } \\
\text { Have-nots: no, as there } \\
\text { is little resource for } \\
\text { ensuring safety on } \\
\text { routes servicing solely } \\
\text { the have-nots }\end{array}$ & $\begin{array}{l}\text { At risk, as, in order } \\
\text { to achieve this } \\
\text { safety, measures } \\
\text { must align with } \\
\text { economic priorities }\end{array}$ & $\begin{array}{l}\text { Yes, as safety is } \\
\text { legislated }\end{array}$ & $\begin{array}{l}\text { Yes, as this will be } \\
\text { desired by the city, the } \\
\text { citizens and the } \\
\text { Metro's operators (all } \\
\text { of whom will value } \\
\text { safety) }\end{array}$ \\
\hline $\begin{array}{l}\text { Is sustainable } \\
\text { (economically, } \\
\text { socially and } \\
\text { environmentally) }\end{array}$ & $\begin{array}{l}\text { At risk. The Metro has } \\
\text { been designed to be } \\
\text { economically } \\
\text { sustainable first, } \\
\text { followed by } \\
\text { environmentally and } \\
\text { socially sustainable }\end{array}$ & $\begin{array}{l}\text { Haves: at risk, as the } \\
\text { haves prioritise safety } \\
\text { and utility over other } \\
\text { factors } \\
\text { Have-nots: at risk, as in } \\
\text { order to achieve } \\
\text { these priorities, they } \\
\text { must align with } \\
\text { maximising use of } \\
\text { limited resources }\end{array}$ & $\begin{array}{l}\text { At risk, as, in order } \\
\text { to achieve social } \\
\text { and environmental } \\
\text { priorities, they } \\
\text { must align with } \\
\text { economic priorities }\end{array}$ & $\begin{array}{l}\text { Yes, as sustainability is } \\
\text { legislated }\end{array}$ & $\begin{array}{l}\text { Yes, as this will be a top } \\
\text { priority for the city, } \\
\text { the citizens and the } \\
\text { Metro's operators (all } \\
\text { of whom will value } \\
\text { sustainability) }\end{array}$ \\
\hline Is accessible to all & $\begin{array}{l}\text { At risk. Excluding some } \\
\text { potential customers } \\
\text { may serve to } \\
\text { maximise profit }\end{array}$ & $\begin{array}{l}\text { Haves: yes, as the } \\
\text { money is available } \\
\text { and other } \\
\text { resources are scarce, } \\
\text { so maximum } \\
\text { functionality must be } \\
\text { achieved } \\
\text { Have-nots: at risk, as } \\
\text { the money and other } \\
\text { resources are not } \\
\text { available to service } \\
\text { the disenfranchised }\end{array}$ & $\begin{array}{l}\text { At risk, as excluding } \\
\text { some potential } \\
\text { customers may } \\
\text { serve to maximise } \\
\text { profit }\end{array}$ & $\begin{array}{l}\text { At risk, as, although } \\
\text { accessibility can be } \\
\text { legislated, those } \\
\text { operating the Metro } \\
\text { may opt to exclude } \\
\text { potential customers in } \\
\text { order to maintain } \\
\text { service delivery (which } \\
\text { is also legislated for) }\end{array}$ & $\begin{array}{l}\text { Yes, as this will be } \\
\text { desired by the city, the } \\
\text { Metro's designers and } \\
\text { the citizens }\end{array}$ \\
\hline
\end{tabular}




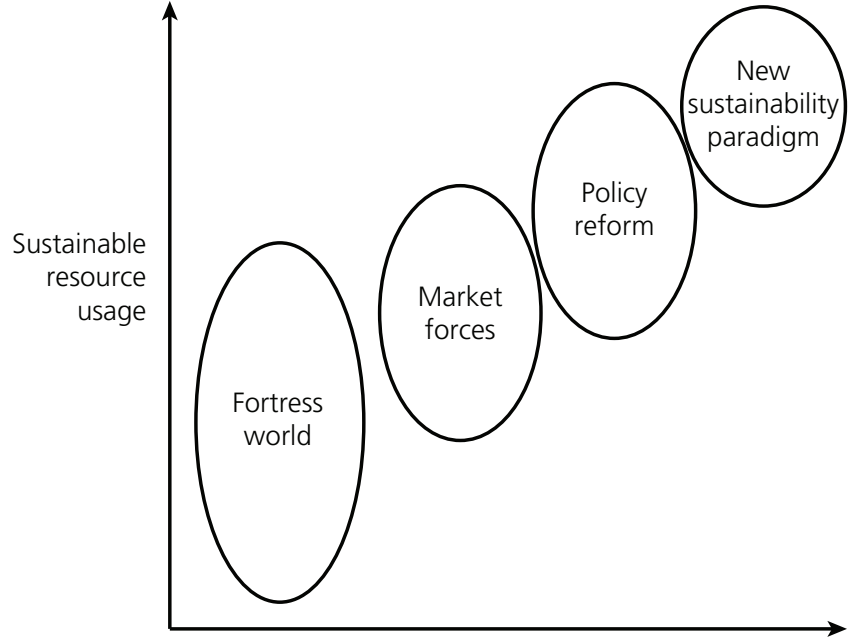

Socio-economic equity

Figure 4. Designing Resilient Cities' four future city scenarios. Adapted from Rogers et al. (2012b)

intervention. For example, it could follow Manchester's lead by augmenting its Metro with a free city centre bus service while at the same time ensuring that the buses are low-carbon and recognising that financing such an intervention may be difficult in the current climate of austerity. Providing strategic linkages with walking and cycling routes to facilitate a 'hop-on, hop-off' mode of travel in uncertain weather (helping to improve citizen health) and ideally aligning the walking/cycling routes with green corridors (bringing people into routine close contact with nature and improving their well-being) would enhance the benefits that could be achieved (Hunt and Rogers, 2015b).

\section{Implications for civil engineering}

This paper uses the LCM in combination with UK City Life ${ }_{1}$ and the Ideal City Model to identify where a city should be in terms of future performance; analyse where it is currently; identify the conditions that need to be in place to support the desired future performance; and make specific recommendations that are optimal for ensuring that those conditions exist today and into the far future. The LCM provides a process for constructing an evidence base and a plausible narrative describing how to get from a city's current performance to a desired future performance. In essence, it establishes the 'business case' for the intervention, from which alternative business models can be constructed directly using the intended benefits to point to the value that is realised (Rogers, 2018), enhanced by systems mapping to enrich the opportunities for value creations and realisation (Bouch and Rogers, 2017; Bouch et al., 2018) and set against alternative forms of investment (Bryson et al., 2018). Through determining how the intervention can deliver multiple benefits to advance the city substantially in its journey towards a more sustainable, resilient and liveable future, it makes the case for transformational change. Such a narrative forms the basis for the engineering strategies that are needed now and in the future.
Civil engineers engineer for the betterment of society and their ultimate client, and their creations are often required to function and deliver their benefits for very many years, usually decades. Equally, what they create is inevitably context dependent - it must function in the context in which it is created, and it must continue to function as the context changes if it is not to become inefficient or redundant. When this context is cities, the context is a highly complex system of systems, all of which are interdependent to different degrees (GO-Science, 2016b): intervene in one system and substantial impacts can be felt in many others. Civil engineers therefore need to develop both a deep understanding of the current context and a broad appreciation of how this context might change into the far future.

Aided by the LCM, civil engineers and civil engineering as a profession can take a more prominent role in addressing the wicked problems of today's cities - such as the energy/water/food nexus, soil nutrient levels, high-density living and well-being; all can be tested using the LCM. Moreover, because of the inherently multidisciplinary spectrum embraced by the civil engineering discipline (Byrne and Mullally, 2014), engineers are well equipped to take a lead in these debates among urban professionals, reaching back to the profession's roots when civil engineering covered the totality of societal support before specialisms initiated by the industrial revolution (mechanical, electrical and electronic, aerospace etc.) were required.

The LCM is at the heart of a set of processes that have been established as good practice in the engineering of cities by a major, and largely coherent, portfolio of research into sustainable urban environments, the resilience of cities and their infrastructure systems and urban liveability. These processes are summarised in Table 4, along with references to some of the sources of evidence generated by the LC team members. However, this is far from (and was never intended to be) complete, and many of the papers published in this journal, for example, will support and enrich the processes, as will the findings from the many UK and international research teams who have been working on these topics. A logical structure to the research findings has been created for the purpose of this discussion. The specific programmes referred to are as follows

- Birmingham Eastside Research (BER) (University of Birmingham, 2018a)

- VivaCity2020 (V2020, 2018) (Cooper et al., 2009)

- Designing Resilient Cities (DRC, 2014; Lombardi et al., 2012)

- the many Sustainable Urban Environment (SUE) programmes, including a three-phased programme of research funded by the Engineering and Physical Sciences Research Council (EPSRC, 2014)

- LC, in particular, the tools, case studies, Little Books and papers (LC, 2018)

- the two consortia researching infrastructure interdependencies and novel business models 


\begin{tabular}{|c|c|}
\hline Lessons from Cities Research Portfolio & Evidence base \\
\hline $\begin{array}{l}\text { To address a specific problem in a city, assemble an appropriately broad, multidisciplinary, } \\
\text { multisectoral group of potentially interested parties who are able to represent the views of all } \\
\text { stakeholders affected by the problem and its potential solutions }\end{array}$ & $\begin{array}{l}\text { BER, V2020, DRC, LC, FULPC, many SUE } \\
\text { projects, the sustainability literature }\end{array}$ \\
\hline $\begin{array}{l}\text { Understand deeply the aspirations of the city and its citizens and the context in which the city exists } \\
\text { (including both its history and its current context) }\end{array}$ & $\begin{array}{l}\text { FFoC, LC, FULPC, BER, V2020, DRC, } \\
\text { Rogers (2018), the sustainability literature }\end{array}$ \\
\hline $\begin{array}{l}\text { Diagnose fully the problem, noting the DRC experience that engineers focus on solutions to } \\
\text { problems while social scientists focus on problem exploration, and other disciplines that lie within } \\
\text { this spectrum - a balance is required }\end{array}$ & ULB, DRC, LC, Leach et al. (2018) \\
\hline $\begin{array}{l}\text { Establish the baseline performance of the city in terms of its sustainability, resilience and liveability. } \\
\text { It is helpful to make explicit the components of the city and infrastructure systems related to the } \\
\text { problem and those that will be impacted by potential interventions by mapping them and } \\
\text { establishing the dependencies and interdependencies between these systems }\end{array}$ & $\begin{array}{l}\text { DRC, Boyko et al. (2012), LC, Leach et al. } \\
\text { (2017a, 2017b), iBuild, Bouch and } \\
\text { Rogers (2017), Bouch et al. (2018), } \\
\text { ULB. Covered explicitly in the LCM }\end{array}$ \\
\hline $\begin{array}{l}\text { Apply ingenuity to the solution of the problem, yielding a number of alternatives from which to } \\
\text { choose the most appropriate }\end{array}$ & Arguably what engineers (should) do \\
\hline $\begin{array}{l}\text { Assess the impact of the interventions on the city's urban and infrastructure systems using one of } \\
\text { the many sustainability assessment frameworks, resilience frameworks and the LC Liveability } \\
\text { Framework (the City Assessment Methodology embodied in UK City Life; see the papers of Leach } \\
\text { et al. (2017a, 2017b)). Iteration will be needed between the design of alternative solutions and } \\
\text { impact assessment }\end{array}$ & $\begin{array}{l}\text { BER, V2020, DRC, SUE, the literature. LC } \\
\text { tools, case studies and papers. Covered } \\
\text { explicitly in the LCM }\end{array}$ \\
\hline $\begin{array}{l}\text { Conduct a futures analysis to explore whether the interventions are vulnerable to future contextual } \\
\text { change (resilient) - that is, they will continue to deliver their benefits and therefore the investment } \\
\text { proves good into the long term }\end{array}$ & $\begin{array}{l}\text { DRC, Lombardi et al. (2012), Rogers et } \\
\text { al. (2012b), LC. Covered explicitly in the } \\
\text { LCM }\end{array}$ \\
\hline $\begin{array}{l}\text { Make the case for change - establish a compelling business case for the proposed intervention. The } \\
\text { LCM was created specifically for this purpose and provides perhaps the most comprehensive } \\
\text { evidence base }\end{array}$ & $\begin{array}{l}\text { While much research supports the } \\
\text { action, this is LC's specific target. } \\
\text { Covered explicitly in the LCM }\end{array}$ \\
\hline $\begin{array}{l}\text { Develop a suite of alternative 'business models' that capture the different forms of value that might } \\
\text { be generated by the intervention, set against the investment required to implement it (perhaps in } \\
\text { different ways) }\end{array}$ & $\begin{array}{l}\text { Much research supports the } \\
\text { identification of economic, social and } \\
\text { environmental value. iBuild and ICIF, } \\
\text { Bouch and Rogers }(2017,2018), \text { Bryson } \\
\text { et al. (2018), Rogers (2018) }\end{array}$ \\
\hline $\begin{array}{l}\text { Understand all of the dimensions of governance (formal and informal) relevant to the intervention } \\
\text { and the context in which it is to be implemented, and engineer changes to all of these systems in } \\
\text { order that the intervention can be implemented without impediment }\end{array}$ & $\begin{array}{l}\text { DRC, LC, Honeybone et al. (2018). } \\
\text { Covered explicitly in the LCM }\end{array}$ \\
\hline $\begin{array}{l}\text { Influence policy by drawing on research findings to help shape local and national government policy } \\
\text { and make the case for the intervention to policymakers }\end{array}$ & $\begin{array}{l}\text { FFoC, FULPC, LC, Honeybone et al. } \\
\text { (2018) }\end{array}$ \\
\hline $\begin{array}{l}\text { Influence practice through tools and case studies that enable the research findings to be translated } \\
\text { to practice }\end{array}$ & V2020, DRC, LC tools and case studies \\
\hline Inform the public of the issues and how they might be addressed & $\begin{array}{l}\text { LC videos and Little Books, ULB, outreach } \\
\text { activities }\end{array}$ \\
\hline
\end{tabular}

BER, Birmingham Eastside Research; DRC, Designing Resilient Cities; FFoC, Foresight Future of Cities; FULPC, University of Birmingham Policy Commission on Future Urban Living; iBuild, Infrastructure Business Models, Valuation and Innovation for Local Delivery; ICIF, International Centre for Infrastructure Futures; SUE, Sustainable Urban Environment; ULB, Urban Living Birmingham; V2020, Viva2020

- Infrastructure Business Models, Valuation and Innovation for Local Delivery (iBuild, 2018)

- International Centre for Infrastructure Futures (ICIF, 2018)

Urban Living Birmingham (ULB, 2018)

- the Foresight Future of Cities (FFoC) project (GO-Science, 2016b; Gov.UK, 2018)

- the University of Birmingham Policy Commission on Future Urban Living (FULPC) (Rogers et al., 2014; University of Birmingham, 2018b).

This research portfolio is now being taken forwards in part under the umbrella of a new multi-university initiative: the UK Collaboratorium for Research on Infrastructure and Cities (UKCRIC, 2018). UKCRIC has seen an investment of $£ 138$ million, matched by institutional and industrial funding, in a suite of new laboratory, urban observatory and modelling and simulation facilities across the UK between 2016 and 2021. It is exploring new ways of working and delivering on collaborative research, exploring, for example, how learning frameworks can support the generation of new knowledge across multidisciplinary teams engaging on engineering challenges (Taylor et al., 2017).

\section{Conclusions}

This paper introduces the LCM, a decision-making process that identifies the conditions that need to be in place to support a sustainable and liveable city of the future and provides an important contribution to building the transitional narrative and engineering strategies needed to get there. In so doing, it provides the essential component when making the case for transformational change towards a more sustainable, resilient and 
liveable future and, crucially, the transformative step to make it happen.

The LCM is demonstrated through the example of Birmingham's ambition to create a more active and inclusive city achieved, in part, by extending its light rail (Metro) system into the city centre. The example follows the nine-step LCM in a linear fashion, starting at step 1 and finishing at step 9, in order to demonstrate the value offered by the method. In doing so, this paper has ignored the necessarily messy and iterative nature of decisionmaking and the fact that it is not always possible, or even desirable, to start at step 1 and work forward, while acknowledging that pervasive iteration is a vital component of the systems thinking that lies at the heart of the LCM. In addition, by focusing narrowly on the given example, the richness of simultaneously considering multiple ambitions and multiple interventions, their sequencing and scales and their arising benefits has been lost. Yet, it is argued by the authors that these have the potential to offer very considerable additional value and insights, for example, by aligning interventions so that they not only simultaneously deliver multiple benefits, but also simultaneously address multiple strategic ambitions.

The example has demonstrated that the LCM provides the necessary decision-making process to engender bold and assured policymaking and, crucially, make explicit how cities can advance towards their common goals of sustainability, resilience and liveability. As one member of Birmingham's City Council explained: society must change how it thinks about making decisions so that it does so in an evidence-based way - this is different from how things are currently done. This has particular implications for engineers, who often consider these common goals as simply 'good engineering' (Keaton, 2017). The LCM facilitates such a transformation by making explicit the thinking behind decisions and by aligning goals, designs and interventions. In doing so, engineers can use the LCM to move actively from 'good engineering' to 'better engineering': '[w] hat we call 'sustainable engineering' today is more than just good engineering, but it is less than what good engineering will become in future decades' (Keaton, 2017: p. 1). By embedding transformation within an evidence-based and repeatable process that encourages innovative approaches for positive additionalities, the LCM overcomes some of the reasons that engineering innovation is 'hard and slow' (Ainger, 2015: p. 9) and contributes to the 'systemic approach to engineering sustainability' called for by this journal in 2014 (Mayfield, 2014: p. 187), a call which continues to be relevant today.

\section{Acknowledgements}

The authors wish to acknowledge the intellectual contributions of all the Liveable Cities researchers through many debates, specifically Christopher J. Bouch, Peter A. Braithwaite, Marianna Cavada, Valeria De Laurentiis, Mike Goodfellow-Smith, Nick Grayson, James D. Hale, Dexter V. L. Hunt, Susan E. Lee, Martin Locret-Collet, Timea Nochta, Jon P. Sadler and Jonathan Ward. The programme was conceived by Rachel Cooper, Brian Collins and AbuBakr Bahaj, alongside Chris Rogers and Nick Tyler, and the authors are indebted to them for their visionary contributions. The authors also gratefully acknowledge the financial support of the UK Engineering and Physical Sciences Research Council under grant numbers GR/S20482, EP/C513177 and EP/E021603 (Birmingham Eastside Regeneration - Sustainable Urban Redevelopment), EP/F007426 (Designing Resilient Cities/Urban Futures), EP/I016133 (Resilience of Critical local Transport and Utility Infrastructure), EP/K012398 (iBuild), EP/J017698 (Liveable Cities), EP/P002021 (Urban Living Birmingham), EP/R013535 (UKCRIC - Plexus) and EP/R017727 (UKCRIC Coordination Node) and the very many researchers and expert panellists with whom they have worked in these research grants.

\section{REFERENCES}

Ainger C (2015) Briefing: Speeding up innovation by better 'first use' reporting. Proceedings of the Institution of Civil Engineers Engineering Sustainability 166(1): 8-10, https://doi.org/10.1680/ensu. 11.00010 .

Arup (2015) City Resilience Index - the Rockefeller Foundation. Arup, London, UK.

Astleithner F and Hamedinger A (2003) The analysis of sustainability indicators as socially constructed policy instruments: benefits and challenges of 'interactive research'. Local Environment 8(6): 627-640, https://doi.org/10.1080/1354983032000152734.

Balmforth D (2015) Civil engineering: fit for the future. Proceedings of the Institution of Civil Engineers - Civil Engineering 168(1): 3-7, https://doi.org/10.1680/cien.2015.168.1.3.

Birmingham City Council (2017) Birmingham Plan 2031: Birmingham Development Plan (Part of Birmingham's Local Plan) - Planning for Sustainable Growth (Adopted January 2017). Birmingham City Council, Birmingham, UK.

Bouch CJ and Rogers CD (2017) A systems thinking approach to the development of alternative infrastructure business models. Proceedings of the International Symposium for Next Generation Infrastructure (ISNGI) 2017, London, UK, pp. 55-63. See http://isngi. org/wp-content/uploads/2017/10/ISNGI-Conference-Proceedings-v2 . pdf (accessed 28/12/2018).

Bouch CJ, Rogers CD, Powell M and Horsfall D (2018) Developing alternative business models for smart infrastructure. Proceedings of the Institution of Civil Engineers - Smart Infrastructure and Construction 171(2): 77-87, https://doi.org/10.1680/jsmic.18.00003.

Bourke F (2015) Birmingham New Street - the amazing facts behind the transformation of the train station. Birmingham Mail, 18 September. See http://www.birminghammail.co.uk/news/midlands-news/ birmingham-new-street-amazing-facts-10083957 (accessed 01/02/ 2016).

Boyko CT, Gaterell MR, Barber AR et al. (2012) Benchmarking sustainability in cities: the role of indicators and future scenarios. Global Environmental Change 22(1): 245-254, https://doi.org/10. 1016/j.gloenvcha.2011.10.004.

Bryson JR, Mulhall RA, Song M et al. (2018) Alternative-substitute business models and the provision of local infrastructure: alterity as a solution to financialization and public-sector failure. Geoforum 95 : 25-34.

Byrne EP and Mullally G (2014) Educating engineers to embrace complexity and context. Proceedings of the Institution of Civil Engineers - Engineering Sustainability 167(6): 241-248, https://doi. org/10.1680/esu.14.00005.

Colantonio A (2010) Urban social sustainability themes and assessment methods. Proceedings of the Institution of Civil Engineers - Urban Design and Planning 163(2): 79-88, https://doi.org/10.1680/udap. 2010.163.2.79. 
Cooper R, Evans G and Boyko C (eds) (2009) Designing Sustainable Cities. Wiley-Blackwell, Oxford, UK

de Silva M and Paris R (2015) Delivering Crossrail, UK: a holistic approach to sustainability. Proceedings of the Institution of Civil Engineers - Engineering Sustainability 168(4): 151-158, https://doi. org/10.1680/ensu.1400037.

Deegan B (2016) Cycling infrastructure in London. Proceedings of the Institution of Civil Engineers - Engineering Sustainability 169(3): 92-100, https://doi.org/10.1680/jensu.15.00001.

DRC (Designing Resilient Cities) (2014) http://designingresilientcities.co.uk (accessed 28/12/2018)

EPSRC (Engineering and Physical Sciences Research Council) (2014) EPSRC Review of the SUE and ARCC Programmes. EPSRC, Swindon, UK. See http://epsrc.ukri.org/newsevents/pubs/suearccreview (accessed 28/12/2018).

Fenner RA, Ainger CM, Cruickshank HJ and Guthrie PM (2006) Widening engineering horizons: addressing the complexity of sustainable development. Proceedings of the Institution of Civil Engineers Engineering Sustainability 159(4): 145-154, https://doi.org/10.1680/ ensu.2006.159.4.145.

Fenner RA, Cruickshank HJ and Ainger C (2014) Sustainability in civil engineering education: why, what, when, where and how. Proceedings of the Institution of Civil Engineers - Engineering Sustainability 167(5): 228-237, https://doi.org/10.1680/ensu.14.00002.

Gaterell M (2013) Editorial. Proceedings of the Institution of Civil Engineers - Engineering Sustainability 166(1): 1-2, https://doi.org/10. 1680/ensu.2013.166.1.1.

Gaterell M (2016) Editorial. Proceedings of the Institution of Civil Engineers - Engineering Sustainability 169(6): 223-224, https://doi. org/10.1680/jensu.2016.169.6.223.

GO-Science (Government Office for Science) (2016a) Future of Cities Foresight for Cities. Foresight and GO-Science, London, UK.

GO-Science (2016b) Future of Cities: the Science of Cities and Future Research Priorities. GO-Science, London, UK.

Gov.UK (2018) Collection: Future of Cities. Government Digital Service, London, UK. See http://gov.uk/government/collections/future-of-cities (accessed 28/12/2018)

Hall JW, Thacker S, Ives MC et al. (2017) Strategic analysis of the future of national infrastructure. Proceedings of the Institution of Civil Engineers - Civil Engineering 170(1): 39-47, https://doi.org/10.1680/ jcien.16.00018.

Honeybone P, Collins BS, Barnes K and Cosgrave E (2018) The Little Book of Governing the City. Liveable Cities, Birmingham, UK.

Hunt DV and Rogers CD (2015a) Aspirational City Futures: a Short Review of Foresight Approaches. Foresight Future of Cities Project and GOScience, London, UK. See http://www.gov.uk/government/publications/ future-of-cities-aspirational-scenarios (accessed 29/11/2018).

Hunt DV and Rogers CD (2015b) Aspirational City Futures: 3 Models for City Living - Workshops (Bristol and Birmingham). Foresight Future of Cities Project and GO-Science, London, UK. See http://www.gov. uk/government/publications/future-of-cities-aspirational-scenarios (accessed 29/11/2018)

Hunt JC, Aktas YD, Mahalov A et al. (2018) Climate change and growing megacities: hazards and vulnerability. Proceedings of the Institution of Civil Engineers - Engineering Sustainability 171(6): 314-326, https:// doi.org/10.1680/jensu.16.00068.

iBuild (Infrastructure Business Models, Valuation and Innovation for Local Delivery) (2018) http://research.ncl.ac.uk/ibuild (accessed 28/12/2018)

ICIF (International Centre for Infrastructure Futures) (2018) http://ucl.ac. uk/steapp/research/projects/icif (accessed 28/12/2018).

Keaton JR (2017) Editorial. Proceedings of the Institution of Civil Engineers - Engineering Sustainability 171(1): 1-2, https://doi.org/10. 1680/jensu.2018.171.1.1.

Kitchin R, Lauriault TP and McArdle G (2015) Knowing and governing cities through urban indicators, city benchmarking and real-time dashboards. Regional Studies, Regional Science 2(1): 6-28, https://doi. org/10.1080/21681376.2014.983149.

LC (Liveable Cities) (2018) http://www.liveablecities.org.uk (accessed 28/12/2018)

Leach JM, Boyko CT, Cooper RF et al. (2015) Do sustainability measures constrain urban design creativity? Proceedings of the Institution of Civil Engineers - Urban Design and Planning 168(1): 30-41, https:// doi.org/10.1680/udap.13.00034.

Leach JM, Braithwaite PA, Lee SE et al. (2016a) Measuring urban sustainability and liveability performance: the City Analysis Methodology. International Journal of Complexity in Applied Science and Technology 1(1): 86-106, https://doi.org/10.1504/IJCAST.2016. 081296.

Leach JM, Lee SE, Kalyviotis N et al. (2016b) Birmingham's Transport Ecosystem: Context and Policy Review. University of Birmingham, Birmingham, UK

Leach JM, Lee SE, Hunt DV and Rogers CD (2017a) Improving city-scale measures of livable sustainability: a study of urban measurement and assessment through application to the city of Birmingham, UK. Cities 71: $80-87$.

Leach JM, Lee SE and Christopher BT (2017b) Dataset of the livability performance of the City of Birmingham, UK, as measured by its citizen wellbeing, resource security, resource efficiency and carbon emissions. Data in Brief 15: 691-695.

Leach JM, Mulhall RA, Rogers CD and Bryson JR (2018) Reading cities: developing an urban diagnostics approach for identifying integrated urban problems with application to the city of Birmingham, UK. Cities, https://doi.org/10.1016/j.cities.2018.09.012.

Lombardi DR, Leach JM and Rogers CD (2012) Designing Resilient Cities: $a$ Guide to Good Practice. IHS BRE Press, Bracknell, UK.

LRF (Lloyd's Register Foundation) (2015) Foresight Review of Resilience Engineering - Designing for the Expected and Unexpected. LRF, London, UK.

Mayer AL (2008) Strengths and weaknesses of common sustainability indices for multidimensional systems. Environment International 34(2): 277-291, https://doi.org/10.1016/j.envint.2007.09.004.

Mayfield M (2014) Editorial. Proceedings of the Institution of Civil Engineers - Engineering Sustainability 167(5): 187-188, https://doi. org/10.1680/ensu.2014.167.5.187.

Mintzberg H and Westley F (2001) Decision making: it's not what you think. MIT Sloan Management Review 42(3): 89-93.

Montgomery M, Broyd T, Cornell S et al. (2012) An innovative approach for improving infrastructure resilience. Proceedings of the Institution of Civil Engineers - Civil Engineering 165(6): 27-32, https://doi.org/ 10.1680/cien.11.00062.

Ness B, Urbel-Piirsalu E, Anderberg S and Olsson L (2007) Categorising tools for sustainability assessment. Ecological Economics 60(3): 498-508.

Ortegon-Sanchez A and Tyler N (2015) Constructing a vision for an 'ideal' future city: a conceptual model for transformative urban planning. Transportation Research Procedia 13: 6-17.

Pearce OJ, Murry NJ and Broyd TW (2012) Halstar: systems engineering for sustainable development. Proceedings of the Institution of Civil Engineers - Engineering Sustainability 165(2): 129-140, https://doi. org/10.1680/ensu.9.00064.

Pires SM, Fidélis T and Ramos TB (2014) Measuring and comparing local sustainable development through common indicators: constraints and achievements in practice. Cities 39: 1-9.

Rogers CD (2018) Engineering future liveable, resilient, sustainable cities using foresight. Proceedings of the Institution of Civil Engineers Civil Engineering 171(6): 3-9, https://doi.org/10.1680/jcien.17.00031.

Rogers CD, Bouch CJ, Williams S et al. (2012a) Resistance and resilience paradigms for critical local infrastructure. Proceedings of the Institution of Civil Engineers - Municipal Engineer 165(2): 73-83, https://doi.org/10.1680/muen.11.00030. 
Engineering Sustainability

Volume 173 Issue 1
The Liveable Cities Method: establishing

the case for transformative change for a

UK metro

Leach, Rogers, Ortegon-Sanchez and Tyler
Rogers CD, Lombardi DR, Leach JM and Cooper RF (2012b) The urban futures methodology applied to urban regeneration. Proceedings of the Institution of Civil Engineers - Engineering Sustainability 165(1): 5-20, https://doi.org/10.1680/ensu.2012.165.1.5.

Rogers CD, Shipley J, Blythe P et al. (2014) Future Urban Living - a Policy Commission Investigating the Most Appropriate Means for Accommodating Changing Populations and Their Needs in the Cities of the Future. University of Birmingham, Birmingham, UK.

Roohnavaz C (2017) Infrastructure construction in developing countries: a shared approach to sustainability. Proceedings of the Institution of Civil Engineers - Engineering Sustainability 171(5): 223-237, https:// doi.org/10.1680/jensu.17.00006.

Shareef SL and Altan H (2017) Building sustainability rating systems in the Middle East. Proceedings of the Institution of Civil Engineers Engineering Sustainability 170(6): 283-293, https://doi.org/10.1680/ jensu.16.00035.

Taylor CA, Crick R, Huang S, Davies R and Cahart N (2017) Learning frameworks for future infrastructure provision. Proceedings of the International Symposium for Next Generation Infrastructure (ISNGI) 2017, London, UK, pp. 386-392. See http://isngi.org/wp-content/ uploads/2017/10/ISNGI-Conference-Proceedings-v2.pdf (accessed 28/12/2018).
UKCRIC (UK Collaboratorium for Research on Infrastructure and Cities) (2018) http://ukcric.com (accessed 28/12/2018).

ULB (Urban Living Birmingham) (2018) http://tinyurl.com/ UrbanLivingBirmingham (accessed 28/12/2018).

UN Desa (UN Department of Economic and Social Affairs) Population Division (2014) World Urbanization Prospects: the 2014 Revision Highlights. UN Desa Population Division, New York, NY, USA, ST/ESA/SER.A/352.

University of Birmingham (2018a) Birmingham Eastside: Sustainable Urban Redevelopment. University of Birmingham, Birmingham, UK. See http://esr.bham.ac.uk (accessed 28/12/2018).

University of Birmingham (2018b) V. Future Urban Living. University of Birmingham, Birmingham, UK. See http://birmingham.ac.uk/research/ impact/policy-commissions/future-urban-living (accessed 28/12/2018).

V2020 (VivaCity2020) (2018) http://vivacity2020.co.uk (accessed 28/12/2018).

WCED (World Commission on Environment and Development) (1987) Report of the World Commission on Environment and Development: Our Common Future. Oxford University Press, Oxford, UK.

Whitehead C (2015) Towards a sustainable infrastructure company. Proceedings of the Institution of Civil Engineers - Engineering Sustainability 168(1): 7-15, https://doi.org/10.1680/ensu.14.00043.

\section{How can you contribute?}

To discuss this paper, please email up to 500 words to the editor at journals@ice.org.uk. Your contribution will be forwarded to the author(s) for a reply and, if considered appropriate by the editorial board, it will be published as discussion in a future issue of the journal.

Proceedings journals rely entirely on contributions from the civil engineering profession (and allied disciplines). Information about how to submit your paper online is available at www.icevirtuallibrary.com/page/authors, where you will also find detailed author guidelines. 